\title{
Poaceae: an overview with reference to Brazil
}

\author{
Poaceae: uma visão geral com referência ao Brasil
}

Hilda Maria Longhi-Wagner ${ }^{1,2}$

\begin{abstract}
A summary of the classification of Poaceae into subfamilies according to different proposals is provided, as well as data on morphology and chorology of grasses, especially those that occur in Brazil. Key words: Gramineae, classification, morphology, geographical distribution, Brazil.

Resumo

É fornecido um sumário da classificação de Poaceae em subfamílias, de acordo com diferentes propostas, bem como dados sobre a morfologia e corologia de gramíneas, especialmente daquelas ocorrentes no Brasil. Palavras-chave: Gramineae, classificação, morfologia, distribuição geográfica, Brasil.
\end{abstract}

\section{Introduction}

The family Poaceae (Gramineae) encompasses approximately 800 genera and 10,000 species (Watson \& Dallwitz 1992), which predominate in the flora and physiognomy of open vegetations all over the world. The economic importance of this family is unquestionable for it has many different types of use, and it includes the major cereals and forages.

Because of the great diversity of Poaceae and its wide variability (Watson \& Dallwitz 1992), researchers have traditionally divided it into subfamilies. This division was initially based on morphological, anatomical, cytological, and chromosomic characters, with molecular data being added more recently. Hence, the number of accepted subfamilies and the characters used to determine them have varied through time. In the seminal publication of GPWG (2001), which proposed a new subfamilial classification of Poaceae based on morphological and molecular data, the authors made a comparison between their classification and the main previous proposals of classification.

The objective of this study is to review different aspects of the taxonomy of Poaceae, including morphology and subfamily classification, and to consider the relationship between chorology and habitat for different groups. An overview of the taxonomic studies of Poaceae in Brazil and of the possibilities within this field of research is also provided.

\section{Classification in subfamilies and its relationship with morphology and chorology}

Several classification systems of Poaceae have been proposed, based mainly on the morphology of the spikelets. Two large groups were accepted: (1) spikelets with two anthecia (see McClure \& Soderstrom 1972), the basal anthecium staminate or neuter (very rarely bisexual) and the apical bisexual, with the articulation between rachilla and pedicel below the glumes; and (2) spikelets exhibiting from one to many anthecia, all bisexual or at least one basal bisexual, and the articulation above the glumes, corresponding, respectively, to the series Panicaceae and Poaceae by Bentham \& Hooker (1880). These groups were later accepted as the subfamilies Panicoideae and Festucoideae, respectively (Hitchcock 1950). Prat (1936) added the subfamily Bambusoideae, also based on anatomical and cytological characters, especially the presence of fusiform cells in the mesophyll. Later, Pilger (1956) accepted a larger number of subfamilies: Andropogonoideae, Anomochlooideae, Eragrostoideae, Festucoideae, Micrairoideae, Olyroideae, Oryzoideae, and Panicoideae.

Parodi (1961) proposed a classification of the Argentinean grasses in the subfamilies Bambusoideae, Oryzoideae, Phragmitoideae, Festucoideae, Eragrostoideae, and Panicoideae. This classification was used for a long time by

\footnotetext{
'Universidade Federal do Rio Grande do Sul, Depto. Botânica, Av. Bento Gonçalves 9500, Prédio 43433, bl. 4, 91501-970, Porto Alegre, RS, Brazil.

${ }^{2}$ Author for correspondance: hmlw@plugin.com.br
} 
agrostologists of Argentina, Uruguay, and southern Brazil, where, due to their role in cattle raising (a very important economic activity in this region), the study of grasses has been well developed. At the same time, Stebbins \& Crampton (1961) proposed to divide the North American grasses into six families, similar to those outlined by Parodi (1961), except for Phragmitoideae, which was named Arundinoideae.

Valls (1980), in his list of the grass genera of Brazil, accepted the same six families mentioned by Stebbins \& Crampton (1961), but named Festucoideae as Pooideae, and Eragrostoideae as Chloridoideae, according to the nomenclatural rules prevailing at that time.

Later, Clayton \& Renvoize (1986) published Genera Graminum, also recognizing these six subfamilies. Pooideae, Chloridoideae, and Panicoideae consisted of the study by Valls (1980), but with a different circumscription for Bambusoideae and Arundinoideae. Bambusoideae included the tribes Oryzeae and Erharteae (Oryzoideae, in Parodi 1961; Stebbins \& Crampton 1961; Valls 1980), and Arundinoideae included the tribes Micraireae and Aristideae. Aristideae was accepted in Chloridoideae by Valls (1980). The sixth subfamily accepted by Clayton \& Renvoize (1986) was Centhotecoideae, which Valls (1980) considered as part of the tribe Centhoteceae, subfamily Arundinoideae.

In addition to their seminal work Genera Graminum (Clayton \& Renvoize 1986), Clayton et al. (2002) were responsible for the development of the project GrassBase - The Online World Grass Flora (<http://www.kew.org/data/grasses-db/. html $>$ ), which uses 1,081 descriptors, most of them morphological, but some also related to geographic distribution, for describing all Poaceae species using the Delta System (Dallwitz et al. 1993). In addition to the descriptions, an interactive key is provided for species identification.

The classification proposed by Clayton \& Renvoize (1986), including subfamilies and tribes, was acknowledged by most agrostologists until the emergence of the classification by the Grass Phylogeny Work Group (GPWG 2001). This new classification proposed twelve subfamilies based on six datasets, five of them molecular and one structural (macro and micro morphology). The main changes in relation to the classification of Clayton \& Renvoize (1986) were: (i) acceptance of Erhartoideae (Oryzoideae) as a subfamily independent of Bambusoideae, following Parodi (1961), Stebbins \& Crampton (1961) and Valls (1980); (ii) the division of part of Bambusoideae into the subfamilies Anomochlooideae, Puelioideae, and Pharoideae, constituting the group with the most basal forest grasses; (iii) the acceptance of the subfamily Aristidoideae encompassing the genera Aristida L., Sartidia De Winter and Stipagrostis Nees, which had been included in Arundinoideae by Clayton \& Renvoize (1986).

Later, based on molecular phylogeny, Sánchez-Ken et al. (2007) acknowledged the inclusion of the tribe Micraireae in the subfamily Micrairoideae, which had been included in Arundinoideae by Clayton \& Renvoize (1986) and incertae sedis (at least the genus Micraira F. Muell.) in GPWG (2001), increasing to 13 the number of subfamilies accepted. The genus Isachne Benth. (ca. three species in Brazil), traditionally included in the tribe Paniceae, subfamily Panicoideae, appeared unexpectedly in the clade Micrairoideae (Sánchez-Ken et al. 2007).

Regarding the number of accepted subfamilies of Poaceae, more recent studies, using new DNA sequences and larger samples, identify only 12 subfamilies again, maintaining Micrairoideae, but placing the subfamily Centothecoideae (represented in Brazil only by the forest genus Orthoclada P. Beauv.) back in the traditional Panicoideae (Sánchez-Ken \& Clark 2007, 2010).

Among the data used by GPWG (2001), characters are related to fruit and embryo (Reeder 1957), leaf anatomy (Ellis 1986), biochemistry of photosynthesis (Brown 1977; Hattersley 1986), and structure of reproductive units, both flowers and spikelets, or equivalent structures (in more basal subfamilies).

The currently accepted subfamilies of Poaceae follows the classification available in Soreng et al. (2011):

Anomochlooideae: this is the lineage that first diverged among Poaceae. It is based on Anomochloa Brong., a monotypic genus, and also includes the genus Streptochaeta Schrad., with ca. three species (Clayton \& Renvoize 1986). These two genera exhibit reproductive structures that correspond to spikelets, but which are not true spikelets and must have appeared before the divergence of the subfamily Pharoideae (GPWG 2001). As synapomorphies of this subfamily, in addition to molecular characters, GPWG (2001) cited the fruit type caryopsis and the lateral embryo, 
which is highly specialized. In addition, there is the presence of fusiform and arm-cells in the mesophyll, characters which are present in most members of other forest Poaceae subfamilies. These two genera are exclusively Neotropical and occur mainly in the Atlantic Forest. Anomochloa marantoidea Brong., known from a few disturbed areas in southern Bahia, is included in the list of endangered species of Brazil published by the Ministry of the Environment (MMA 2008). The genus Streptochaeta has two species in tropical Brazil (Filgueiras \& Gonçalves 2006); among them, only one, S. spicata Nees, occurs up to the northern coast of Rio Grande do Sul, following the southern boundary of the Brazilian Atlantic Forest.

Pharoideae: this is the next divergent lineage of Poaceae, in which occur the typical reproductive structures of the family: the spikelets. Its spikelets are formed by two glumes and one anthecium (lemma and palea), both in staminate and pistillate spikelets, and the plants are monoecious. The two types of spikelets are assembled in pairs in each node of the inflorescence; staminate spikelets are considerably smaller than pistillate ones. A strong morphological synapomorphy is the presence of a twist on the pseudopetiole of the leaf, which makes the abaxial surface of the leaf face up, unlike other Poaceae. This subfamily occurs in the tropics of the Old and New World and is represented in Brazil by the genus Pharus P. Browne, with four species (Filgueiras \& Santos-Gonçalves 2004; Filgueiras et al. 2012).

Puelioideae: this is the next divergent lineage (GPWG 2001), which also includes forest grasses, represented by the genera Guaduella Franch. and Puellia Franch., the former with six species and the latter with five. These are endemic to Africa, and are distributed from Serra Leone to Angola (Clayton \& Renvoize 1986).

The above-mentioned subfamilies are the most basal in the phylogeny of Poaceae; they occur in forests with a predominantly tropical distribution. Their members usually exhibit fusiform and arm-cells in the mesophyll and absence of Kranz anatomy, and have clearly (or presumably, in the case of Anomochlooideae and Puelioideae, according to GPWG 2001) $\mathrm{C}_{3}$ photosynthesis.

According to GPWG (2001), all the remaining subfamilies form a large clade that diversified early and includes two smaller clades. One of these is the clade BEP (including Bambusoideae, also predominantly forest grasses, Ehrartoideae, and
Pooideae), which is exclusively $\mathrm{C}_{3}$, and the other clade is PACCAD (Panicoideae, Arundinoideae, Chloridoideae, Centothecoideae, Aristidoideae, and Danthonioideae). This second clade also has Kranz syndrome in most of its members, and it is assumed that this syndrome evolved more than once in Poaceae (GPWG 2001). More recently, Sánchez-Ken et al. (2007) denominated the clade PACCAD as PACCMAD, because the subfamily Micrairoideae was included. Clark (2009) named this clade PACMAD, as recent studies suggested the inclusion of Centothecoideae in Panicoideae (Sánchez-Ken \& Clark 2007).

Bambusoideae: this subfamily has also $\mathrm{C}_{3}$ photosynthesis and occurs predominantly in forests. However, contrarily to the abovementioned subfamilies, Bambusoideae is highly diversified, including approximately 1,400 species (Clark 2009). For Brazil, Filgueiras \& Santos-Gonçalves (2004) estimated 232 native species; this number was updated by Filgueiras et al. (2012) as 266 species, among which 159 are endemic. In its current state, it includes bamboos that are herbaceous, monoecious, polycarpic, with staminate and pistillate spikelets in the same plant in the tribe Olyreae, and bamboos that are lignified, with bisexual spikelets, and which are usually monocarpic multiannual, in the tribes Bambuseae (tropical) and Arundinarieae (temperate), according to Clark (2009) and Soreng et al. (2011 onwards).

Members of the tribe Arundinarieae occur mainly in montane regions of Asia and in lower degree, North America, without native members in Brazil. Olyreae is an almost exclusively Neotropical tribe and includes several species that are either native or endemic to Brazil, with the exception of Olyra latifolia L., which occurs also in Africa (whether it is native or introduced is still under discussion), and Burgersiochloa Pilg., a monotypic genus from New Guinea (Clayton \& Renvoize 1986). The diversity center of Olyreae is located in the Atlantic Forest of southern Bahia and northern Espírito Santo (Soderstrom et al. 1988; Oliveira 2006), and new species are constantly found, as studies are intensified in these areas (Oliveira et al. 2008 $a, b)$. The tribe Bambuseae exhibits two diversity centers, one in Asia and one in the Neotropics, with several members in the Atlantic Forest, many of which are endemic. In this tribe many new species have also been described (Sendulsky 1995, 1997; Clark 1996, 2004; Filgueiras \& Londoño 2006; Santos-Gonçalves et al. 2011), and some revisions 
have been made (Guala 2003; Santos-Gonçalves 2005; Viana 2010). Probably, the tribes Olyreae and Bambuseae are also well represented in the Amazon Forest, though there are few records due to the lower sampling intensity in the region.

The subfamily Bambusoideae needs more studies in Brazil, including intensive collecting in the Atlantic Forest and Amazon, which would probably reveal new and endemic species, both among lignified and herbaceous bamboos. An analysis of the distribution and conservation of herbaceous bamboos was published by Oliveira $e t$ al. (2006), and an analysis of the native bamboos of Brazil was published by Filgueiras \& SantosGonçalves (2006). Furthermore, there are different research groups studying the commercial use of lignified bamboos (Almeida \& Teixeira 2006).

Many governmental measures have been implemented in order to advance the knowledge and use of bamboos. One of the most important measures was the creation of the Center for the Study of Bamboos and Natural Fibers (Centro de Estudos de Bambus e Fibras Naturais) at the University of Brasília and the National Bamboo Network (Rede Nacional do Bambu).

Erhartoideae: this subfamily was included in Bambusoideae by Clayton \& Renvoize (1986), in part due to the presence of fusiform and armcells in some of its members. These types of cells do not occur in other Poaceae, except for the genera Homolepis Chase and Streptostachys Desv. (Panicoideae), according to GPWG (2001). This subfamily exhibits bisexual spikelets with characteristically very reduced or even absent glumes. It comprises ca. 120 species (GPWG 2001) that inhabit moist sites, such as marshes and river banks. Burman (1985) reported the occurrence of ca. 19 species for Brazil, a number very close to the 20 species reported by Filgueiras et al. (2012), including two cultivated species. This subfamily needs to be studied in detail, particularly the genera Luziola Juss. and Leersia Sol. ex Sw.

Pooideae: the circumscription of this family underwent few modifications in the system of GPWG (2001), compared with Clayton \& Renvoize (1986). However, the circumscription of tribes in the two aforementioned classifications was profoundly changed in comparison with previous classifications, such as that of Parodi (1961), in particular with the division of Poeae (sensu lato, in Parodi 1961) into the tribes Poeae sensu stricto, Bromeae, and Meliceae, and with the inclusion of Aveneae in Poeae as a subtribe (Aveninae). Pooideae includes ca. 3,300 species (GPWG 2001), and it is the main subfamily of microthermic grasses. In southern Brazil and neighboring countries, they contribute significantly to the production of forage during winter, which is a crucial period for natural pastures. Its species exhibit usually membranous ligule, spikelets with the basal bisexual anthecia and articulation above the glumes, which persist in the inflorescence after the fall of mature anthecia, lemmas with five or more nerves, and $\mathrm{C}_{3}$ photosynthesis. Burman (1985) reported 128 species for Brazil, whereas 135 are listed in Filgueiras et al. (2012), 25 of which are endemic. The highest species richness occurs in the natural grasslands of Rio Grande do Sul state, a few species extending to the "campos de altitude" or, in smaller numbers, to the rocky fields ("campos rupestres") of southeastern Brazil. The main winter crops of southern Brazil belong to this subfamily, e.g. wheat, barley, rye and oat. Although this subfamily is already well-documented in Brazil (Kämpf 1975; Longhi-Wagner 1987; Zanin et al. 1992), one aspect that still requires further studies is the northern limit of its distribution within the country, which was published only for the genus Stipa L. (LonghiWagner \& Zanin 1998).

Danthonioideae: this subfamily was described by Barker \& Linder in GPWG (2001), grouping part of the genera previously accepted in Arundinoideae sensu lato. It includes ca. 250 species, all $\mathrm{C}_{3}$ (GPWG 2001). It is represented in Brazil by the genera Cortaderia Stapf, with three native species and Danthonia DC., with five native species (Santos \& Boechat 1989), as well as the genus Hakonechloa Makino ex Honda, with one subspontaneous species (Filgueiras et al. 2012). Some native species occur in southern Brazil. A few native species have been found in low abundance in high-altitude fields of southeastern Brazil; one of them, Danthonia montana Pilg., is found all the way to the high altitude fields of Bahia (Morro do Chapéu). This is the northernmost limit known for microthermic grasses in Brazil (Longhi-Wagner \& Oliveira 2002).

Arundinoideae: this subfamily had its circumscription drastically reduced in the study by GPWG (2001); it was not considered to be well-defined, needing further studies, since no morphological synapomorphy was found to support its monophyly. In the systems of Parodi (1961, as Phragmitoideae) and Stebbins \& Crampton (1961, as Arundinoideae), as well as of Valls (1980), this 
subfamily includes many genera with Brazilian native species, such as Cortaderia, Gynerium Willd. ex P. Beauv., Danthonia, and Phragmites Adans. In the classification proposed by Watson \& Dalwitz (1992), Arundinoideae included even the tribe Stipeae, which is currently within the subfamily Pooideae. In Clayton \& Renvoize (1986), it includes the tribes Aristideae and Micraireae, both later accepted as independent subfamilies (GPWG 2001; Sanchez-Ken et al. 2007).

Arundinoideae had always been a subfamily with a difficult circumscription, and its current form (GPWG 2001) includes 33 to 38 species, all $\mathrm{C}_{3}$. It has only one representative in Brazil, Phragmites australis (Nees) Döll, a species considered cosmopolitan, of swamps and riverbanks.

Micrairoideae: includes ca. 170 species distributed mainly in Australia and Asia, less commonly in the Neotropics, in open savannas or edges of forest. Most of them have $\mathrm{C}_{3}$ photosynthesis, except for species of the genera Eriachne $\mathrm{R}$. Br. and Pheidochloa S.T. Blake, which do not occur in Brazil (GPWG 2001). This subfamily is represented in tropical Brazil by four species of the genus Isachne $\mathrm{R}$. Br., a genus which includes approximately 100 species that are mainly distributed in Asia (Clayton \& Renvoize 1986). Isachne was included by Filgueiras et al. (2012) in the subfamily Panicoideae, to which it previously belonged. These plants have stoloniferous habits, occur in forest edges, and exhibit morphology similar to the tribe Paniceae, namely spikelets with deciduous glumes and two anthecia, but with both bisexual and coriaceous anthecia. Isachne is one of the grass genera that need urgent revision in Brazil.

Aristidoideae: this subfamily was originally described by Caro (1961), but it was not adopted by later authors. GPWG (2001) accepted this subfamily with three genera: Aristida L., with ca. 250 pantropical species, of which 36 occur in Brazil (Filgueiras et al. 2012); Sartidia Winter, with four African species and $\mathrm{C}_{3}$ photosynthesis; and Stipagrostis Nees, with ca. 50 African and Asian species, $\mathrm{C}_{4}$ photosynthesis, and only one Kranztype sheath around the vascular bundles. Aristida was reported as a genus with $\mathrm{C}_{4}$ photosynthesis by GPWG (2001) and other authors, with a double Kranz sheath (Brown 1977). However, recently Cerros-Tlatilpa \& Columbus (2009) discovered an Aristida species $\mathrm{C}_{3}$ without Kranz anatomy, A. longifolia Trin., which occurs from Central America to central and southeastern Brazil, in cerrado, caatinga, and shaded sites next to riparian forests (Longhi-Wagner 1999). It is possible that other Aristida $\mathrm{C}_{3}$ species could be found, as the number of sampled species increases. This is an interesting topic for studies on this genus in Brazil.

Chloridoideae: the circumscription of this subfamily did not change much in the system of GPWG (2001), compared to the system of Clayton \& Renvoize (1986). In relation to previous systems, such as that of Parodi (1961) and Valls (1980), the greatest modification was the separation of Aristida in a different subfamily, as mentioned above. It is interesting to emphasize that, in Clayton \& Renvoize (1986), this genus was included in Arundinoideae. Members of Chloridoideae exhibit spikelets with one or more basal bisexual anthecia, with persistent glumes, as in Pooideae, but the ligule is usually pilose or membranous-ciliate, and the lemma is 3 -nerved. Besides, it is a very homogeneous subfamily in terms of presence and type of Kranz syndrome (Brown 1977), with only one African species of Eragrostis Wolf and one of Merxmuellera Conert known as $\mathrm{C}_{3}$ (GPWG 2001). Members of this subfamily are usually found in grasslands, often in arid environments, and very occasionally occurr on forest edges, but not inside forests. It includes ca. 1,400 species (GPWG 2001). For Brazil, Burman (1985) estimated 157 species, including species of Aristida. Filgueiras et al. (2012) listed 161 species, but excluded Aristida, which is currently accepted in Aristidoideae.

Recently, Columbus et al. (2007) published a phylogenetic analysis of the subfamily Chloridoideae, modifying the circumscription of some tribes.

Panicoideae: the subfamily Panicoideae belongs to a Poaceae lineage that developed spikelets with the articulation between the rachilla and the pedicel located below the glumes (both glumes and mature anthecia are deciduous), and only two anthecia, the upper one is bisexual and the lower one is generally staminate or neuter. These characteristics distinguish it from most Poaceae, in which the spikelets usually have basal bisexual anthecia and persistent glumes.

According to GPWG (2001), Panicoideae includes 3,270 species, most with $\mathrm{C}_{4}$ photosynthesis of three different biochemical subtypes (Brown 1977; Hattersley 1986), but it also includes $C_{3}$ species. Among these, there are stoloniferous species of the tribe Paniceae that occur inside forests, covering the forest ground (species of Oplismenus P. Beauv., Pseudechinolaena Stapf 
and Ichnanthus P. Beauv., among others), or with scandent habits (Lasiacis (Griseb.) Hitchc.). However, apparently there is no strong relationship between habitat and photosynthesis type. There are $\mathrm{C}_{3}$ species that occur typically in open and arid environments, for example those of the genera Apochloa Zuloaga \& Morrone and Renvoizea Zuloaga \& Morrone, which previously belonged to Panicum L. group Lorea (Sede et al. 2008). Those species inhabit outcrops in the "campos rupestres" of Cadeia do Espinhaço, southeastern Brazil. Likewise, Echinolaena inflexa (Poir.) Chase, a grass considered as typical of the Cerrado, is $\mathrm{C}_{3}$. It is important to highlight that most species of the tribe Paniceae occur in grasslands, cerrados, rocky fields, and aquatic environments (Allem \& Valls 1987) all over Brazil.

Burman (1985) estimated the existence of 838 Panicoideae species in Brazil, and Filgueiras et al. (2012) listed 778 species. It is by far the most diversified subfamily of Poaceae in Brazil and its species predominate in grasslands, even in southern Brazil, where the microthermic subfamily Pooideae is highly diversified. Due to its importance as a key element of Brazilian grasslands and cerrados, and due to its high richness of genera and species, this subfamily needs further taxonomic revisions in addition to those already made (e.g. Canto-Dorow 2001; Boechat 2005; Oliveira 2004; Zuloaga \& Morrone 2005; Zanin \& Longhi-Wagner 2006). The published surveys of Brazilian floras are also important, such as Valls et al. (2001) and Oliveira \& Valls (2001), who studied the important genera Axonopus P. Beauv. and Paspalum L., respectively. Moreover, it must be taken into account that Panicoideae includes genera of great importance for natural pastures, most notably Paspalum, which has been the subject of multidisciplinary studies aimed at its commercial use (Quarín et al. 1997; Casa et al. 2002; Souza-Chies et al. 2005; Machado et al. 2005; Miz \& Souza-Chies 2006; Pozzobon et al. 2008).

The changes that have been proposed for the internal classification of the subfamily Panicoideae are focused mainly on the inclusion of the subfamily Centothecoideae, on changes in the circumscription of genera and, to a lesser degree, tribes (Sánchez-Ken \& Clark 2010). For example, the genus Panicum has been subjected to several phylogenetic studies that led to the transference of many of its species to other genera of the tribe Paniceae or even to new genera, whereas the circumscription of Paspalum has undergone minor modifications (Denham et al. 2002; Denham 2005; Zuloaga et al. 2007; Morrone et al. 2008a; Sede et al. 2008; Zuloaga \& Morrone 2009).

According to Filgueiras et al. (2012), the remarkable number of 238 species of Panicoideae are endemic to Brazil.

\section{Poaceae in Brazil}

As previously mentioned among Poaceae subfamilies, only Puelioideae is not represented in Brazil, though Micrairoideae is still not included in the list of Brazilian grasses (Filgueiras et al. 2012). In subfamilies that include megathermic species of predominantly tropical distribution (i.e., all that were previously mentioned, except Danthonioideae and Pooideae) there is usually a pronounced decrease in species richness towards southern Brazil, as well as a decrease in population density and size. An example is the tribe Olyreae of herbaceous bamboos, of which, according to the data currently available only the genera Olyra L. and Parodiolyra Soderstr. \& Zuloaga reach the state of Rio Grande do Sul, the first genus with two species and the second with one, following the southern limit of the Atlantic Forest. As for the mainly tropical tribe Bambuseae, which includes lignified bamboos, the decrease in diversity towards southern Brazil is less pronounced: Schmidt \& Longhi-Wagner (2009) recorded five genera with 27 native species in Rio Grande do Sul.

Some genera of grasses that are more diversified in the tropics present two different patterns of distribution in Brazil, one including species predominantly or exclusively tropical and another including species predominantly or exclusively extratropical. Examples of these patterns are Aristida (Aristidoideae), and Eragrostis (Chloridoideae). The distribution patterns of the species of Eragrostis native to Brazil were analyzed by Boechat \& Longhi-Wagner (2000).

On the other hand, members of Pooideae and Danthonioideae have a distribution predominantly extratropical in Brazil, with a pronounced decrease in species richness, density, and population size from south to north.

One of the first studies of Brazilian grasses was published by Raddi (1823), a member of the group of scientists that arrived in Brazil with the Princess Maria Leopoldina of Austria. Raddi remained in Brazil from 1817 to 1818 , collecting plants in the state of Rio de Janeiro and its surroundings. His collections served as a basis for the publication of 
Agrostografia brasiliensis (Raddi 1823), which was recently analyzed by Baldini \& Longhi-Wagner (2006) and Longhi-Wagner \& Baldini (2007).

Nees (1829) published the study Agrostologia brasiliensis, which included 83 genera and 403 species, emphasizing the high number of species waiting to be described. In Flora brasiliensis, the grasses were studied by Döll (1871-1877) and by Hackel (1883), including several new species.

The historical collections, on which the publications cited above were based, are deposited in different European herbaria and are relatively wellknown. However, there are other historical collections, also in European herbaria, that remain to be studied and that can reveal taxonomic and nomenclatural novelties, as pointed out by Baldini (2009).

Valls (1980) estimated the occurrence of more than 180 Poaceae genera in Brazil and Burman (1985) published an estimate of 197 genera and 1,368 species. In the 1990s, many new species, and even genera, were published (Longhi-Wagner 1994; Filgueiras 1996; Sendulsky 1997; Boechat \& Longhi-Wagner 1998; Filgueiras et al. 2001; Zanin \& Longhi-Wagner 2003; Guglieri et al. 2006a; Oliveira \& Longhi-Wagner 2007; Oliveira et al. 2008 a,c; Oliveira \& Valls 2009, among others). In the List of Species of the Brazilian Flora, Filgueiras et al. (2012) mentioned 210 genera of Poaceae, of which 21 are endemic, and 1,414 species, of which 468 are endemic.

Checklists of species of Poaceae were published for a number of regions of Brazil. Longhi-Wagner \& Renvoize (2006) listed 99 genera and 421 species for northeastern Brazil, and Rezende et al. (2008) listed 91 genera and 510 for the Cerrado (Central Brazil). In addition, Morrone et al. (2008b) listed 203 genera and 1,528 species (540 endemic) for the Uruguay, Argentina, Paraguay and the three states of southern Brazil.

Checklists like those mentioned above or even less comprehensive lists provide important data for phytogeographic analysis and lay the ground for surveys and conservation studies. However, as they do not provide analytic keys or illustrations, they need to be complemented by taxonomic revisions that allow species identification. Publications of regional floras and taxonomic revisions are very useful and urgently needed. Once these data become available, they would be the basis for the implementation of public policies aimed at the sustained use and conservation of native resources in different regions of the country.
It is important to emphasize that only a few Brazilian states include Poaceae in their published floras (Smith et al. 1981-1982; Renvoize 1984, 1988; Filgueiras 1995; Longhi-Wagner et al. 2001). However, a great number of floristic surveys of smaller areas have been published and provide the basis for studies in other fields of research, such as phytosociology, floristic, and ecology (e. g. Burman et al. 1987; Rocha et al. 2001; Rocha \& Secco 2004; Longhi-Wagner \& Todeschini 2004; Welker \& Longhi-Wagner 2007; Ferreira et al. 2009), contributing substantially to the knowledge of the Brazilian agrostological flora.

Several genera revisions for Brazil have already been published (Sendulsky \& Soderstrom 1984; Filgueiras 1984, 1989; Boechat \& LonghiWagner 1995, 2001; Longhi-Wagner 1999; Oliveira \& Valls 2002, Guglieri et al. 2006b; Zanin \& Longhi-Wagner 2006). Due to the continental dimensions of Brazil, revisions comprising the whole country are frequently hindered by the difficulty of collecting with the necessary intensity. It is important, however, that these revisions are carried out, even if intensive sampling is conducted only in a part of a taxon's range (more accessible to researchers), and the work is complemented by the analysis of herbarium material for the remaining areas. Such studies will have a far-reaching impact and will bring advancements in the knowledge of Poaceae in Brazil.

\section{Final Considerations}

As the subfamily classification of Poaceae tends to stabilize, current phylogenetic studies focus mainly on the analysis of the circumscription of tribes (e. g. Columbus et al. 2007) and genera (e. g. Zuloaga et al. 2007; Morrone et al. 2008a; Sede et al. 2008; Rua et al. 2010). Unfortunately, although these analyses are very important, few studies with this focus are being conducted in Brazil (e. g. Oliveira 2006; Essi et al. 2008). Likewise, ontogenetic analyses (Sajo et al. 2007, 2008; Nakamura \& Scatena 2009; Nakamura et al. 2009) and population analyses (Oliveira et al. 2008b) are scarce in Brazil, even though they are extremely valuable.

Data obtained with the above-mentioned approaches are essential for biodiversity analysis, survey of hotspots, and for conservation programs. The Official List of Endangered Species of Brazil (MMA 2008) contains 14 Poaceae, of which seven are from the Atlantic Forest, one is shared between 
the Atlantic Forest and the Pampa, five are from the Cerrado, and only one is from the Amazon. However, a much higher number of species could be under threat, but were not assessed due to data deficiency. Among these are many Amazonian bamboo species, known only through their type material, which have never been collected again.

Hence, the study of Poaceae in Brazil must focus mainly on intensive field collection in several areas, such as the Amazon and other areas that have been relatively poorly sampled. Taxonomic revisions and floristic studies should also be continued and have their publication stimulated. The training of human resources in different regions of the country is also important, especially in the northern and northeastern regions, where specialists in Poaceae are still lacking. There is also a need for more agrostologists to be enlisted as supervisors in graduate programs in Botany. Finally, it is necessary to promote cooperation between researchers using different approaches, so that Brazilian agrostologists can contribute not only to a more complete survey on this important family in the country, but also to the advancement of its knowledge at a global level.

\section{Acknowledgements}

The Brazilian National Council for Scientific and Technological Development (CNPq) granted us a research fellowship. Anonymous reviewers made invaluable suggestions to the manuscript.

\section{References}

Allem, A.C. \& Valls, J.F.M., 1987. Recursos forrageiros nativos do pantanal mato-grossense. EMBRAPA, Depto. Difusão e Tecnologia, Brasília. 339p.

Almeida, J.G. \& Teixeira, A.A. 2006. Estruturação da rede de pesquisa e desenvolvimento em bambu. Seminário Nacional de Bambu: Anais, Brasília.

Baldini, R.M. \& Longhi-Wagner, H.M. 2006. Poaceae Raddianae: an updated nomenclatural and taxonomical evaluation of G. Raddis's Brazilian Poaceae. Taxon 55: 469-482.

Baldini, R.M. 2009. An outlook at the historical collections of Neotropical Poaceae in the European herbaria. In: Moura, C.W.N.; Silva, T.R.S.; Giulietti-Harley, A.M. \& Santos, F.A.R. (eds.) Botânica brasileira: futuro e compromissos. Resumos. Pp. 229-233.

Bentham, G. \& Hooker, J.D. 1880. Genera Plantarum. Vol. 3, pt. 1. L Reeve, Londini.

Boechat, S.C. 2005. O gênero Ichnanthus (PoaceaePanicoideae-Paniceae) no Brasil. Iheringia 60: 189-248.
Boechat, S.C. \& Longhi-Wagner, H.M. 1995. O gênero Sporobolus (Poaceae: Chloridoideae) no Brasil. Acta Botanica Brasilica 9: 17-73.

Boechat, S.C. \& Longhi-Wagner, H.M. 1998. Duas novas espécies de Eragrostis (Poaceae, Chloridoideae) do Brasil. Iheringia 51: 177-187.

Boechat, S.C. \& Longhi-Wagner, H.M. 2000. Padrões de distribuição dos táxons brasileiros de Eragrostis (Poaceae - Chloridoideae). Revista Brasileira de Botânica 23: 177-194.

Boechat, S.C. \& Longhi-Wagner, H.M. 2001. O gênero Eragrostis (Poaceae) no Brasil. Iheringia 55: 23-169.

Brown, W.V. 1977. The Kranz syndrome and its subtypes in grass systematic. Memoirs of the Torrey Botanical Club 23: 331-422.

Burman, A.G. 1985. Nature and composition of grass flora of Brazil. Willdenowia 15: 211-233.

Burman, A.G.; Sendulsky, T.; Longhi-Wagner, H.M. \& Renvoize, S.A. 1987. Gramineae. In: Giulietti, A.M.; Menezes, N.L.; Pirani, J.R.; Meguro, M.; Wanderley, M.G.L. (eds.). Flora da Serra do Cipó, Minas Gerais: caracterização e lista das espécies. Boletim de Botânica 9: 117-123.

Canto-Dorow, T.S. 2001. O gênero Digitaria no Brasil. Tese de Doutorado. Universidade Federal do Rio Grande do Sul, Porto Alegre. 386p.

Caro, J.A. 1961. Las especies de Aristida (Gramineae) del Centro de la Republica Argentina. Kurtziana 1: 123-206.

Casa, A.M.; Mitchell, S.E.; Lopes, C.R. \& Valls, J.F.M. 2002. RAPD analysis reveals genetic variability among sexual and apomictic Paspalum dilatatum Poiret biotypes. Journal of Heredity 93: 300-302.

Cerros-Tlatilpa, R. \& Columbus, T. 2009. C 3 photosynthesis in Aristida longifolia: implications for photosynthetic diversification in Aristidoideae (Poaceae). American Journal of Botany 96: 1379-1387.

Clark, L.G. 1992. Chusquea sect. Swallenochloa (Poaceae: Bambusoideae) and allies in Brazil. Brittonia 44: 387-422.

Clark, L.G. 1996. Four new species of Chusquea (Poaceae: Bambusoideae) from Brazil and Ecuador. Brittonia 48: 250-262.

Clark, L.G. 2004. Two new species of Aulonemia and Chusquea (Poaceae: Bambusoideae) from Brazil. Revista Brasileira de Botânica 27: 31-36.

Clark, L.G. 2009. Subfamilial classification of the Poaceae, with emphasis on the Bambusoideae. In: Moura, C.W.N.; Silva, T.R.S.; Giulietti-Harley, A.M. \& Santos, F.A.R. (eds.) Botânica brasileira: futuro e compromissos. Resumos. Pp. 218-222.

Clayton, W.D. \& Renvoize, S.A. 1986. Genera Graminum. Grasses of the world. Her Maj. Stat. Office, London. 389p.

Clayton, W.D.; Vorontsova, M.S.; Harman, K.T. \& Williamson, H. 2002 onwards. World grass species: 
descriptions, identification, and information retrieval. Available in $<$ http://www.kew.org/data/ grasses-db.html $>$. Access on 2 Feb 2012.

Columbus, J.T.; Cerros-Tlatilpa, R.; Kinney, M.S.; Siqueiros-Delgado, M.E.; Bell, H.L.; Griffith, M.P. \& Refulio-Rodriguez, N.F. 2007. Phylogenetics of Chloridoideae (Gramineae): a preliminary study based on nuclear ribosomal internal transcribed spacer and chloroplast trnL-F sequences. Aliso 23: 567-579.

Dallwitz, M.J.; Paine, T.A. \& Zurcher, E.J. 1993 (onwards). User's guide to the DELTA System: a general system for processing taxonomic descriptions. 4 th edition. Available in $<\mathrm{http}$ //deltaintkey.com>. Access on 2 Feb 2012.

Denham, S.S. 2005. Revisión sistemática del subgénero Harpostachys de Paspalum (Poaceae: Panicoideae: Paniceae). Annals of the Missouri Botanical Garden 92: 463-532.

Denham, S.S.; Zuloaga, F.O. \& Morrone, O. 2002. Systematic revision and phylogeny of Paspalum subgenus Ceresia (Poaceae: Panicoideae: Paniceae). Annals of the Missouri Botanical Garden 89: 337-399.

Döll, J.C. 1871-1877. Gramineae I. In: Martius, C.F.P. von \& Eichler, A.W. (eds.). Flora brasiliensis Vol. 2, pt. 2. Pp. 1-357.

Ellis, R.P. 1986. A review of comparative leaf blade anatomy in the systematic of Poaceae: the past twenty five years. In: Soderstrom, T.R.; Hilu, K.W.; Campbell, C.S. \& Barkworth, M.E. (eds.). Grass systematics and evolution. Smithsonian Institution Press, Washington D.C. Pp. 3-10.

Essi, L.; Longhi-Wagner, H.M. \& Souza-Chies, T.T. de, 2008. Phylogenetic analysis of the Briza Complex (Poaceae). Molecular Phylogenetics and Evolution 47: 1018-1029.

Ferreira, F.M.; Costa, A. \& Forzza, R.C. 2009. Aristidoideae, Chloridoideae, Danthonioideae e Pooideae (Poaceae) no Parque Estadual de Ibitipoca, Minas Gerais Brasil. Boletim de Botânica da Universidade de São Paulo 27: 189-202.

Filgueiras, T.S. 1984. O gênero Cenchrus L. no Brasil (Gramineae: Panicoideae). Acta Amazonica 14: 95-127.

Filgueiras, T.S. 1989. Revisão de Mesosetum Steudel (Gramineae: Paniceae). Acta Amazonica 19: 47-114.

Filgueiras, T.S. 1995. Gramineas dos estados de Goiás e Tocantins. In: Rizzo, J.A. (ed.). Flora dos estados de Goiás e Tocantins. Vol. 17. J. Rizzo, Goiânia. Pp. 1-143.

Filgueiras, T.S. 1996. Arthropogon rupestris (Poaceae: Arthropogoneae) a new species from the Brazilian cerrado vegetation and a revised key for the genus. Nordic Journal of Botany 16: 69-72.

Filgueiras, T.S.; Davidse, G.; Zuloaga, F.O. \& Morrone, O. 2001. The establishment of the new genus
Altoparadisium and a reevaluation of Arthropogon (Poaceae: Paniceae). Annals of the Missouri Botanical Garden 88: 351-372.

Filgueiras, T.S. \& Santos-Gonçalves, A.P. 2004. A checklist of the basal grasses and bamboo in Brazil (Poaceae). The Journal of the American Bamboo Society 18: 7-18.

Filgueiras, T.S. \& Santos-Gonçalves, A.P. 2006. Bambus nativos no Brasil: oportunidades e desafios para o seu conhecimento. Seminário Nacional de Bambu: Anais. Brasília. Pp. 33-43.

Filgueiras, T.S. \& Londoño, X. 2006. A new giant species of Guadua (Poaceae: Bambusoideae) from Central Brazil. Seminário Nacional do Bambu: Anais. Brasília. Pp. 27-32.

Filgueiras, T.S.; Longhi-Wagner, H.M.; Viana, P.L.; Zanin, A.; Guglieri, A.; Oliveira, R.C.; CantoDorow, T.S.; Shirasuna, R.T.; Valls, J.F.M.; Oliveira, R.P.; Rodrigues, R.S.; Santos-Gonçalves, A.P., \&Welker, C.A.D. 2012. Poaceae. In: Lista de espécies da flora do Brasil. Jardim Botânico do Rio de Janeiro. Available in $<$ http://floradobrasil.jbrj. gov.br/2012/FB000193>. Access on 2 Feb 2012.

GPWG - Grass Phylogeny Working Group. 2001. Phylogeny and subfamilial classification of the grasses (Poaceae). Annals of the Missouri Botanical Garden 88: 373-457.

Guala, G.F. 2003. A new genus of bamboos from the Cerrados of Brazil. The Journal of the American Bamboo Society 17: 1-3.

Guglieri, A.; Longhi-Wagner, H.M. \& Zuloaga, F.O. 2006a. Panicum complanatum (PoaceaePanicoideae-Paniceae). Systematic Botany 31: 506-511.

Guglieri, A.; Longhi-Wagner, H.M. \& Zuloaga, F.O. 2006b. Panicum L. subg. Panicum sect. Panicum (Poaceae) no Brasil. Hoehnea 33: 185-217.

Hackel, E. 1883. Gramineae IV. In: Martius, C.F.P. von \& Eichler, A.W. (eds.). Flora brasiliensis. Vol. 2, pt. 3. Pp. 246-326.

Hattersley, P.W. 1986. Variations in photosynthetic pathway. In: Soderstrom, T.R.; Hilu, K.W.; Campbell, C.S. \& Barkworth, M.E. (eds.). Grass systematics and evolution. Smithsonian Institution Press, Washington D.C. Pp. 49-64.

Hitchcock, A.S. 1950. Manual of the grasses of the United States. 2 ed. rev. A. Chase. U.S.D.A., Washington. 1051p.

Kämpf, A.N. 1975. As gramíneas da tribo Agrosteae ocorrentes no Rio Grande do Sul. Anuário Técnico do IPZFO 2: 541-679.

Longhi-Wagner, H.M. 1987. Flora ilustrada do Rio Grande do Sul. Fasc. 17. Gramineae - tribo Poeae. Boletim do Instituto de Biociências 41: 1-191.

Longhi-Wagner, H.M. 1994. Aristida (Poaceae): two new species from Brazil. Kew Bulletin 49: 817-821. 
Longhi-Wagner, H.M. 1999. O gênero Aristida (Poaceae) no Brasil. Boletim do Instituto de Botânica 12: 113-179.

Longhi-Wagner, H.M. \& Baldini, R. 2007. Synopsis Poacearum in Josephii Raddii Agrostografia brasiliensis. Kew Bulletin 62: 381-405.

Longhi-Wagner, H.M.; Bittrich, V.; Wanderley, M.G.L. \& Shepherd, J.G. 2001. Poaceae. In: Wanderley, M.G.L.; Shepherd, G.J. \& Giulietti, A.M. (eds.). Flora fanerogâmica do estado de São Paulo. Vol. 1. Pp. 1-292. Hucitec, São Paulo.

Longhi-Wagner, H.M. \& Oliveira, R.P. 2002. New grass records for Bahia State, Brazil. Kew Bulletin 57: 971- 977.

Longhi-Wagner, H.M. \& Renvoize, S.A. 2006. Poaceae. In: Barbosa, M.R.V.; Sothers, C.; Mayo, S.; GamarraRojas, C.F.L. \& Mesquita, A.C. (eds.). Checklist das plantas do nordeste brasileiro. Vol. 1. Brasília. Pp. 91-97.

Longhi-Wagner, H.M. \& Todeschini, B.H. 2004. Flora de Grão Mogol, Minas Gerais: Gramineae (Poaceae). Boletim de Botânica da Universidade de São Paulo 22: 143- 165 .

Longhi-Wagner, H.M. \& Zanin, A. 1998. Padrões de distribuição geográfica das espécies de Stipa L. (Poaceae - Stipeae) ocorrentes no Brasil. Revista Brasileira de Botânica 21: 167-175.

McClure, F.A. \& Soderstrom, T.R. 1972. The agrostological term anthecium. Taxon 21: 153-154.

Machado, A.C.C.; Valls, J.F.M.; Peñaloza, A.P.S. \& Santos, S. 2005. Novos biótipos pentaplóides do grupo Dilatata de Paspalum L. (Gramineae) no Sul do Brasil. Ciência Rural 35: 56-61.

Miz, R.B. \& Souza-Chies, T.T. 2006. Genetic relationships and variation among biotypes of dallisgrass (Paspalum dilatatum Poir.) and related species using random amplified polymorphic DNA markers. Genetic Resources and Crop Evolution 53: 541-552.

MMA - Ministério do Meio Ambiente. 2008. Lista oficial das espécies da flora brasileira ameaçadas de extinção. Instrução Normativa de setembro 2008, anexo I

Morrone, O.; Denham, S.S.; Giussani, L.M. \& Zuloaga, F.O. 2008a. Parodiophyllochloa, a new genus segregated from Panicum (Paniceae, Poaceae) based on morphological and molecular data. Systematic Botany 33(1): 66-76.

Morrone, O.; Zuloaga, F.O.; Longhi-Wagner, H.M.; Izaguirre, P.; Beyhaut, R.; Cialdella, A.M.; Giussiani, L.; Denham, S.S.; Guglieri, A.; Boldrini, I.I.; Zanin, A.; Salariato, D. \& De Gennaro, D. 2008b. Poaceae. In: Zuloaga, F.O.; Morrone, O. \& Belgrano, M.J. Catálogo de las plantas vasculares del Cono Sur (Argentina, sur de Brasil, Chile, Paraguay y Uruguay). Monographs in Systematic Botany from the Missouri Botanical Garden 1: 705-1063.
Nakamura, A.T.; Longhi-Wagner, H.M. \& Scatena, V.L. 2009. Desenvolvimento de óvulo, fruto e semente de espécies de Poaceae (Poales). Revista Brasileira de Botânica 32: 165-176.

Nakamura, A.T. \& Scatena, V.L. 2009. Desenvolvimento pós-seminal de espécies de Poaceae (Poales). Acta Botanica Brasilica 23: 212-222.

Nees, C.C. 1829. Agrostologia brasiliensis. In: Martius, C.F.P. Flora Brasiliensis Enumeratio Plantarum 2. J.G. Cottae, Stuttgartiae.

Oliveira, R.C. 2004. Estudo taxonômico das espécies de Paspalum grupo Plicatula (Poaceae- PanicoideaePaniceae) no Brasil. Tese de Doutorado. Universidade Estadual de Campinas, Campinas. 366p.

Oliveira, R.C. \& Valls, J.F.M. 2001. Paspalum. In: Wanderley, M.G.L.; Shepherd, G.J. \& Giulietti, A.M. (eds.). Flora fanerogâmica do estado de São Paulo. Vol. 1. Hucitec, São Paulo. Pp. 191-228.

Oliveira, R.C. \& Valls, J.F.M. 2002. Taxonomia de Paspalum L. grupo Linearia (Gramineae - Paniceae) do Brasil. Revista Brasileira de Botânica 25: 371-389.

Oliveira, R.C. \& Valls, J.F.M. 2009. Duas novas espécies de Paspalum L. (Poaceae: Paniceae) do Brasil. Revista Brasileira de Botânica 32: 89-94.

Oliveira, R.P. 2006. Estudos taxonômicos, filogenéticos e biossistemáticos em Raddia Bertol. (Poaceae: Bambusoideae: Olyreae). Tese de Doutorado. Universidade Estadual de Feira de Santana, Feira de Santana. 311p.

Oliveira, R.P. \& Longhi-Wagner, H.M. 2007. New species of Streptostachys (Poaceae: Paniceae) from Brazil. Kew Bulletin 62: 493-497.

Oliveira, R.P.; Longhi-Wagner, H.M. \& Jardim, J.G. 2006. Diversidade e conservação de bambus herbáceos (Poaceae: Bambusoideae: Olyreae) da Mata Atlântica, Brasil. Seminário Nacional de Bambu: Anais. Brasília. Pp. 62-66.

Oliveira, R.P.; Borba, E.L. \& Longhi-Wagner, H.M. 2008a. Morphometrics of herbaceous bamboos of the Raddia brasiliensis Complex (PoaceaeBambusoideae): implications for the taxonomy of the genus and new species from Brazil. Plant Systematics and Evolution 270: 159-182.

Oliveira, R.P.; Borba, E.L.; Longhi-Wagner, H.M.; Pereira, A.C.S. \& Lambert, S.M. 2008b. Genetic and morphological variability in the Raddia brasiliensis Complex (Poaceae: Bambusoideae). Plant Systematics and Evolution 274: 25-35.

Oliveira, R.P.; Longhi-Wagner, H.M.; Leite, K.R.B. \& Hollowell, V. 2008c. Pariana multiflora (Poaceae, Bambusoideae, Olyreae), a new species from Eastern Brazil, with notes on the leaf anatomy of the genus. Systematic Botany 33: 262-266.

Parodi, L. 1961. La taxonomia de las gramíneas argentinas a la luz de las investigaciones más recentes. Recent Advances in Botany 1: 125-130. 
Pilger, R. 1956. Gramineae II. In: Engler, A. \& Prantl, K. (eds.). Die Natürlichen Pfanzenfamilien. Vol. 14. Duncker \& Hum blot, Berlin. 225p.

Pozzobon, M.T.; Machado, A.C.C.; Vaio, M.; Valls, J.F.M.; Peñaloza, A.P.S.; Santos, S.; Côrtes, A.L.A. \& Rua, G.H. 2008. Cytogenetic analyses in Paspalum L. reveal new diploid species and accessions. Ciência Rural 38: 1292-1299.

Prat, H. 1936. La systématique des Graminées. Annales des Sciences Naturelles Botanique 10: 165-258.

Quarín, C.L.; Valls, J.F.M. \& Urbani, M.H. 1997. Cytological and reproductive behavior of Paspalum atratum, a promising forage grass for the Tropics. Vol. 31. Tropical Grasslands, St. Lucia. Pp. 114-116.

Raddi, G. 1823. Agrostografia brasiliensis. Attir. Accad. Luchese Sci, Lett. Ed Artii 2: 329-383 (Reimpresso como Agrostografia brasiliensis. Pp. 1-58, pl. 1. Tip. G. Nerici, Lucca, 1823).

Reeder, J.R. 1957. The embryo in grass systematics. American Journal of Botany 44: 756-769.

Renvoize, S.A. 1984. The grasses of Bahia. Royal Botanic Gardens, Kew. Pp 1-300.

Renvoize, S.A. 1988. Hatschbach’s Paraná grasses. Royal Botanic Gardens, Kew. Pp 1-76.

Rezende, A.V.; Walter, B.M.T.; Fagg, C.W.; Felfili, J.M.; Silva Júnior, M.C.; Nogueira, P.E.; Mendonça, R.C. \& Filgueiras, T.S. 2008. Flora vascular do bioma cerrado. In: Sano, S.M.; Almeida, S.P. \& Ribeiro, J.F. (eds.). Cerrado: ecologia e flora. Embrapa, Brasília. Pp. 1028-1059.

Rocha, A.E.S.; Bastos, M.N.C. \& Secco, R.S. 2001. O gênero Panicum L. (Poaceae) na Restinga da Praia da Princesa, APA de Algodoal/Maiandeua, Maracanã, Pará, Brasil. Boletim do Museu Paraense Emílio Goeldi 17: 297-314.

Rocha, A.E.S. \& Secco, R.S. 2004. Contribuição à taxonomia de Axonopus P. Beauv. (Poaceae) no Estado do Pará, Brasil. Acta Botanica Brasilica 18: 295-304.

Rua, G.H.; Speranza, P.R; Vaio, M. \& Arakaki, M. 2010. A phylogenetic analysis of the genus Paspalum (Poaceae) based on cpDNA and morphology. Plant Systematics and Evolution 288: 227-243.

Sajo, M.G.; Longhi-Wagner, H.M. \& Rudall, P.J. 2007. Floral development and embryology in the earlydivergent grass Pharus. International Journal of Plant Sciences 1688: 181-191.

Sajo, G.M.; Longhi-Wagner, H.M. \& Rudall, P. 2008. Reproductive morphology of the earlydivergent grass Streptochaeta. Plant Systematics and Evolution 275: 245-255.

Sánchez-Ken, J.G.; Clark, L.G.; Kellogg, E.A. \& Kay, E.E. 2007. Reinstatement and emendation of subfamily Micrairoideae (Poaceae). Systematic Botany 32: 71-80.

Sánchez-Ken, J.G. \& Clark, L.G. 2007. Phylogenetic relationships within the Centothecoideae and
Panicoideae clade (Poaceae), based on $n d h \mathrm{~F}$ and rpl16 intron sequences and morphological data. Aliso 23: 487-502.

Sánchez-Ken, J.G. \& Clark, L.G. 2010. Phylogeny and a new tribal classification of the Panicoideae s.l. (Poaceae) based on plastid and nuclear sequences and structural data. American Journal of Botany 97: 1732-1748.

Santos, A.M.P.V. \& Boechat, S.C. 1989. Flora Ilustrada do Rio Grande do Sul XX. Gramineae - tribo Danthonieae. Boletim do Instituto de Biociências 344: 1-57.

Santos-Gonçalves, A.P. 2005. Estudos taxonômicos e morfoanatômicos em Colanthelia (Poaceae: Bambusoideae: Bambuseae). Tese de Doutorado. Universidade Estadual de Campinas, Campinas. 161p.

Santos-Gonçalves, A.P.; Filgueiras, T.S. \& Clark, L.G. 2011. Atractantha shepherdiana, a new species of woody bamboo from Brazil. Systematic Botany 36: 310-313.

Schmidt, R. \& Longhi-Wagner, H.M. 2009. A tribo Bambuseae (Poaceae, Bambusoideae) no Rio Grande do Sul, Brasil. Revista Brasileira de Biociências 7: 71-128.

Sede, S.M.; Morrone, O; Giussani, L.M. \& Zuloaga, F.O. 2008. Phylogenetic studies in the Paniceae (Poaceae): a realignment of section Lorea of Panicum. Systematic Botany 33: 284-300.

Sendulsky, T. 1995. Merostachys multiramea (Poaceae: Bambusoideae: Bambuseae) and similar species from Brazil. Novon 5: 76-96.

Sendulsky, T. 1997. Twelve new species of Merostachys (Poaceae: Bambusoideae: Bambuseae) from Brazil. Novon 7: 285-307.

Sendulsky, T. \& Soderstrom, T.R. 1984. Revision of the South American genus Otachyrium (Poaceae: Panicoideae). Smithsonian Contributions to Botany 57: 1-24.

Smith, L.B.: Wasshausen, D.C. \& Klein, R.M. 19811982. Gramíneas. In: Reitz, R. (ed.). Flora ilustrada catarinense. Herbário Barbosa Rodrigues, Itajaí. $1407 p$.

Soderstrom, T.R.; Judziewicz, E.J. \& Clark, L.G. 1988. Distribution patterns of neotropical bamboos. Proceedings of a workshop on neotropical distribution patterns. Academia Brasileira de Ciências, Rio de Janeiro. Pp. 121-157.

Soreng, R.J.; Davidse, G.; Peterson, P.M..; Zuloaga, F.O.; Judziewicz, E.J.; Filgueiras, T.S. \& Morrone, O. 2011 onwards. A world-wide phylogenetic classification of Poaceae (Gramineae). Available in $<$ http://www. tropicos.org/docs/meso/CLASSIFICATION\%20 OF\%20world\%20grasses\%202011\%20Dec\%2013. htm>. Access on 2 Feb 2012.

Souza-Chies, T.T.; Essi, L.; Rua, G.H.; Valls, J.F.M. \& Miz, R.B. 2005. Filogenia de Paspalum L. com 
base em ITS (rDNAnu). In: Congresso Brasileiro de Melhoramento de Plantas, 3. Anais. Embrapa Trigo, Sociedade Brasileira de Melhoramento de Plantas, Passo Fundo. Pp. 1-7.

Stebbins, G.L. \& Crampton, B. 1961. A suggested revision of the grass genera of temperate North America. Recent Advances in Botany 1: 133-144.

Valls, J.F.M. 1980. Gramíneas nativas e sua importância forrageira: situação do estudo no Brasil. EMBRAPA, Plantas forrageiras, Brasília. Pp. 7-23.

Valls, J.F.M.; Longhi-Wagner, H.M. \& Boldrini, I.I. 2001. Axonopus. In: Wanderley, M.G.L.; Shepherd, G.J. \& Giulietti, A.M. (eds.). Flora fanerogâmica do estado de São Paulo. Vol. 1. Hucitec, São Paulo. Pp. 129-141.

Viana, P.L. 2010. O gênero Aulonemia Goudot (Poaceae: Bambusoideae) no Brasil. Tese de Doutorado. Universidade Federal de Minas Gerais, Belo Horizonte. 272p.

Watson, L. \& Dallwitz, M.F. 1992. The grass genera of the world. Cambridge University Press, Cambridge. $1081 \mathrm{p}$.
Welker, C.A.D. \& Longhi-Wagner, H.M. 2007. A família Poaceae no Morro Santana, Rio Grande do Sul, Brasil. Revista Brasileira de Biociências 5: 53-92

Zanin, A. \& Longhi-Wagner, H.M. 2003. Taxonomic novelties in Andropogon (Poaceae-Andropogoneae) for Brazil. Novon 13: 368-375.

Zanin, A. \& Longhi-Wagner, H.M. 2006. Sinopse do gênero Andropogon L. (Poaceae - Andropogoneae) no Brasil. Revista Brasileira de Botânica 29: 289-299.

Zanin, A.; Mujica-Salles, J. \& Longhi-Wagner, H.M. 1992. A tribo Stipeae no Rio Grande do Sul e Brasil. Boletim do Instituto de Biociências 51: 1-174.

Zuloaga, F.O.; Giussiani, L.M. \& Morrone, O. 2007. Hopia, a new monotypic genus segregated from Panicum (Poaceae). Taxon 56: 145-156.

Zuloaga, F.O. \& Morrone, O. 2005. Revisión de las especies de Paspalum para America del Sur Austral. Missouri Botanical Garden, Saint Louis. 297p.

Zuloaga, F.O. \& Morrone, O. 2009. Phylogenetic studies in the Paniceae (Poaceae - Panicoideae): Ocellochloa, a new genus from the new world. Systematic Botany 34: 684-692. 